\title{
The Individual Agency and Social Structure Dialectic: Exploring Women's Experiences of Remand Custody through Arts and Community-Based Research
}

\author{
Gayle Rutherford", Christine A. Walsh, Meredith Klemmensen and Sarah Madden \\ Faculty of Nursing, University of Calgary, 2500 University Dr. N.W., Calgary, AB T2N 1N4, Canada
}

\begin{abstract}
Background: Attention to the interaction between individual agency and the structural causes and solutions to repeated incarceration is important to create sustainable change. In order to create this change, we will need to work in new ways to investigate the issues and to collaboratively identify and implement solutions.

Purpose: Arts-and community-based research methods were used to explore the experiences and personal knowledge of women in remand custody.

Results: The findings substantiate current knowledge of the underlying causes of women's incarceration, including both structural issues (e.g., poverty, inaccessible education and employment, housing instability) and personal issues (e.g., addictions, history of family violence). Although the women acknowledged individual responsibility, attention to the structural causes and solutions to the cycling in and out of incarceration is fundamentally important, underpinning all of the women's recommendations.

Conclusion: The challenge of reducing the cycle of repeated incarceration for women will require a concerted collaborative effort using creative endeavors that bring the knowledge and experience of the women together with key players who can influence change at both the individual and the systemic levels.
\end{abstract}

Keywords: Women, remand custody, community-based research, arts-based research, structural social work theory.

\section{As I sit within these prison walls}

I ask myself, how far must someone fall?

When will I get it through my head?

If I don't change now, l'll end up dead.

While in remand custody, many women develop hopes and dreams for a different future, but after release have limited opportunity to fulfill those dreams and return to their previous lives on the street. Attention to the interaction between individual agency and the structural causes and solutions to repeated incarceration is fundamentally important to create sustainable change. In order to create this change, we will need to work in new ways to investigate the issues and to collaboratively identify and implement solutions. It is particularly important that we find ways to involve the women in these processes.

Women disproportionately experience structural inequities related to sexism, poverty, inaccessible education and employment, and housing instability, potentially making crime more tempting and leading to a cycle in and out of incarceration (Shantz, Kilty and

*Address correspondence to this author at the Faculty of Nursing, University of Calgary, 2500 University Dr. N.W., Calgary, AB T2N 1N4, Canada; Tel: 403220-6984; Fax: 403-284-4803; E-mail: geruther@ucalgary.ca
Frigon 2009, Walsh, Rutherford and Kuzmak 2009). For individuals who are also homeless, the chances of reoffending and returning to incarceration are high (Baldry et al. 2006). Homeless women who are also incarcerated encounter a double stigma, leading to enormous challenges in establishing successful lives in the community. Women also face personal obstacles, such as addictions or mental health conditions, which complicate their situation, further stigmatize them, and if not dealt with, could lead to or exacerbate continued legal and housing issues (McNaughton and Sanders 2007).

In this paper we examine the experiences of women in remand custody using a structural social work theory perspective in order to gain a better understanding of the interaction between the women's individual agency for change and a structural system linked to the root causes of social problems (Murray and Hick 2008). Structural social work emphasizes how decreased opportunities, resources, and power results in oppression of individual and groups of people. Rather than ignoring individual agency, structural social work "takes a dialectical approach wherein individual agency and social structures are understood to be engaged in a mutually reinforcing relationship; each organizes and perpetuates the other" (Murray and Hick 2008:11). At the same time, structural social work theory acknowledges the historical perspective of colonialism 
when understanding the present conditions of oppression among Aboriginal peoples (Baskin 2003). Structural social work theory also reinforces the need for individuals most affected by the issues to participate in social change and addresses not only individual difficulties but the need for change within society as a whole (Murray and Hick 2008).

The impetus for this research came from stories of women who had cycled between living on the streets and spending time in the Calgary Remand Centre (CRC) where they awaited trial or sentencing, or served time for unpaid tickets they frequently could not afford to pay, repeatedly cycling in and out due to lack of accessible and appropriate intervention.

\section{Purpose}

- To explore the experiences and personal knowledge of women directly affected by cycling in and out of incarceration,

- To meet with the women during a period of time when they were in remand custody,

- $\quad$ To use an arts-based approach as a basis for our interactions,

- $\quad$ To understand reasons why women cycle in and out of incarceration,

- $\quad$ To have the women identify solutions to break the cycle,

- $\quad$ To have the women and the researchers to gain a better understanding of the issues surrounding the women's cycling in and out of incarceration, and

- $\quad$ To work together to find ways to break the cycle and improve the lives of women with these experiences.

\section{Goal}

- $\quad$ To serve as a first step in working collaboratively toward social change and improving lives of women with similar experiences,

To build relationships with women who had experienced repeated remand custody, initially while they were in CRC, and then later in the community after their release, and

To highlight the dichotomy between the individual agency of the women to create change in their lives while dealing with structural issues beyond their control.

\section{METHODOLOGY}

Community-based research principles provided a foundation for this research. Community-based research aims to empower communities to create knowledge that represents community issues and addresses community concerns both locally and across broader contexts. Knowledge created through this process is practical and improves the well-being of participants and the community as a whole (Delman and Lincoln 2009). Community-based research focuses on partnerships between academics and community partners based on principles of co-learning, mutual benefit, capacity-building, and long-term commitment with a goal of social change (Wallerstein and Duran 2006). In addition, we integrated arts-based research methodology as a means for the women to find their voices (Foster 2007) and actively participate in informing others about the issues they were facing (Huss 2009, Rolling 2010). Arts-based activities shaped our conversations and facilitated collaboration between the researchers and the women at the same time as helping to mitigate the negative impacts of the coercive prison environment (Allspach 2010).

We received ethics approval through the University of Calgary Conjoint Faculties Research Ethics Board and the Alberta Solicitor General and Public Security Research Department. The research team consisted of two academic researchers (GR, CW) and two student researchers (SM, MK). At least one academic researcher and one student researchers met weekly with women at the CRC in the Chapel over a period of 11 weeks. The meetings were approximately 1.5 hours long, starting after lunch and ending before the afternoon cell count. The group meetings reached a reasonable conclusion at the eleventh meeting, when most of the women were new to the meetings and those who previously participated had been released or transferred to another institution.

\section{Participants}

Twenty-five women completed the informed consent process, and 21 women attended one or more meetings. Between five and 12 women attended each meeting. Three women were being remanded for the first time, while others had been remanded or incarcerated more than once, ranging from months to over 20 years in and out of prison. The women's ages 
ranged from 19 to 41 years, with a median age of 30 years. Sixteen women claimed Aboriginal heritage. The high percentage of Aboriginal women in the study is not surprising, since $28 \%$ of women in remand custody in Canada are Aboriginal, in stark contrast to the proportion in the overall Canadian adult population of 3\% (Calverley 2010).

\section{Data Collection and Analysis}

We used an informal group structure responsive to the women's needs and interests each week. Typical meetings included warm-up questions; sharing stories and experiences related to cycling in and out of incarceration; viewing music videos, reading poetry, and dance; and creating artwork using pencil crayons and paper supplied through CRC. The women also used exercise notebooks and pens provided by CRC to do 'home work' between group meetings, where they wrote reflections and poetry to share with the researchers and other group members. The music video, dancing, drawing, and poetry reading exercises primarily served to open conversations and encourage women express their thoughts and feelings creatively and without coercion. Women's responses to the group activities revealed common themes of their experiences contributing to their cycling in and out of jail. The personal poetic and prose written pieces the women created facilitated their self-reflexivity and selfexpression of individual experiences.

Data from this study included field notes of conversations and observations written by student researchers during the meetings, team field notes and reflections written after the meetings, along with the writing and artwork of the women. All of these data were combined and coded into themes using QSR NVivo 8, a software data analysis program. Common themes reflected meeting conversations and included points such as strength, hope, how to deal with sobriety and a non-chaotic life, plans for release, support needs for release as well as freestyle writing on whatever stories the women felt others needed to hear. The stories of the women framed the following findings.

\section{FINDINGS}

The overall purpose of the study was to gain a better understanding of the reasons why women cycle in and out of incarceration as well as to have the women identify solutions to break the cycle. Both the physical and social elements of the environment of our meetings influenced the group dynamic positively. We met in the CRC Chapel each week, sitting in a circle, sharing beverages and snacks provided through the CRC kitchen. In the beginning, we noticed a divide in seating arrangement based both on Aboriginal or nonAboriginal status, and between the researchers and the women. We purposefully attempted to alter where we positioned ourselves in the circle in order to move the focus from the researchers to the voices of the women. Over time, the division between the Aboriginal and nonAboriginal women became less obvious. However, the Aboriginal women appeared to be dealing with deeper cultural and historical issues that had influenced their life trajectories individually and as families (Walsh et al. 2011), providing them with more connection through their stories than for the non-Aboriginal women without this common history. In all of the findings, we saw a dialectic between what the women felt was their responsibility and a sense of inability to deal with systems and historical events beyond their control.

\section{Reasons for Cycling in and out of Incarceration}

Through the sharing of stories and experiences, the women helped us all to understand the underlying causes of the cycling in and out of incarceration. Although spending time in the CRC was not something they desired, they had mixed feelings about the available alternatives. The women expressed fear they would return to old destructive habits when released. Release was not always a completely positive experience; there were many risks of losing control, with one woman writing, "Am I safer here than I am out there?" However, their remand experience also contributed to a lack of control for the women because they were in confined quarters and closely monitored. The women told us, "CRC is the most locked down prison in Canada, so you have a lot of time to think. If you're an easy going person it's easy to adjust but if you're scared you'll have a hard time."

\section{History of Violence Victimization and Trauma}

Almost all of the women spoke about a history of physical, sexual, and emotional violence, often beginning in childhood and persisting into adulthood. Although clearly extremely painful, violence appeared to be a normative, a common experience. One woman said, "it causes a lot of pain to be in love, it's all you know." Instability in their lives and attraction to chaos grew with repeated incidence of violence: "It's like we are addicted to the trauma.....constant battle and tension is what keeps you intrigued". These experiences of violence and victimization were 
debilitating, causing the women to feel trapped: "I would like to have something to show for myself instead of bruises and tears."

Growing up was painful, abused, beaten, and left behind

Starving, dirty, alone, not knowing which way to go.

Strangers, all around me with fake smiles at night,

Morning comes with pain

Doing my hiding game

I thought and prayed, it ended, when I was little

Through my trials and tribulations, lost everything, even me.

\section{Drug and Alcohol Addictions}

Many of the women spoke of the impact of addictions on their lives and acknowledged the connection between cycles of violence and addictions with the chaos in their lives. "Most of the people are good people in here; it usually comes down to addictions." Addictions offered momentary escape and fleeting enjoyment: "An addict can describe the high of their drug that sounds so attractive, who wouldn't want to try it?" At the same time, addictions were connected to bad relationships and past circumstances that they knew they needed to break away from. The women talked about not caring about anything when they were using, other than the 'adrenaline rush,' 'money,' 'dealers,' and 'the life.' Yet, they also talked about losing everything due to the addictions. They moved back and forth between talking about the 'highs' of the drug life to the 'lows' of the associated losses. One woman said she wanted to be honest with us; she did not want to quit drugs: "I'm not going to fool you. When I get out I will use drugs. When you see me on the street, no matter how bad I look, don't worry about me. I will have God with me."

One non-Aboriginal woman said her background was different from other women in the group. She believed she had everything she ever needed as a child, and was never abused, never hungry, but grew "tired of pretending to be perfect" when she was about 17 years old. She described feeling instantly accepted by the people with whom she used drugs because, as she described herself, she was naïve and "I always had money to support my habit and everyone else's." She was forced into treatment eight times without success.
She stated, "When I left rehab for the first time, I learned all about how much better smoking coke was, then injecting it, then heroin, and so on." She likened people with addictions to chameleons - good actresses or actors: "we become such good liars that we begin to believe our own bullshit!" She wrote about the impact of addictions on her life in this poem:

As I look in the mirror I wonder, who's this I see?

A ghostly looking skeleton stares back at me.

I plunge the syringe in my vein- it contains too much.

But my thumb hits the bottom, my skin feels hot to touch.

My heart's beating faster, my knees grow weak.

There's no turning back now- I can't even speak.

My body crashes down to the linoleum floor,

I look up for a moment- I should unlock the door.

For if I am to die here, l'd hate to burden thee

Who has to break down the door to discover me.

With a needle in my arms and my eyes wide open

Surrounded by drugs and my blood soakin'

Have you ever heard you reap what you sow?

I wasn't always this way, but who'd ever know?

\section{Family and Friends}

Family had both positive and negative associations for the women. The family environment could be a place of trauma and chaos, or a source of strength and guidance. One woman shared the story of how, at the age often, she was made to inject her mother with illegal drugs, "and if I couldn't or didn't hit the vein, I would get a lickin." Other women spoke of their mothers and grandmothers as a source of strength, survivors through a life of struggles. Many of the women had children in the care of others, often with government authorities. Some of the women appeared upset when thinking about what they had put their children through and what they had been missing in their children's lives when they had been 'high' or in jail. They described missing so much, "birthdays, holidays, school." One woman spoke about wanting to protect her children from traumatization from her 
incarceration. She did not tell them where she was, rather explaining she was sick and getting better. She sent them cards for all of the holidays, "and they drew cards and sent them back to me, which really made me happy."

Two women spoke of how their partners led them into a life of drugs and crime. One woman said she got into an abusive relationship with a member of organized crime: "I got involved and made some really poor choices and never in a million years would I have believed I'd have ended up in jail, but - here I am." Another woman spoke about how she had lived in an abusive relationship for years and felt like her husband had stolen eight years of her life by pushing crack on her. The women also spoke about the importance of leaving family and friends who were bad influences behind, to begin a new life. "It's the people you surround yourself with who put you at risk." They spoke of regret about what they were missing:

If I could turn back time,

l'd be somewhere else,

Some where besides here.

If I could turn back time,

l'd be loved, always trusted,

And always strong with family and friends.

\section{Resource Gaps and System Failures}

The women spoke about making plans to stay clean and improving their lives when they were inside, but when they got out "and it's cold and you have nowhere safe to go, it's hard to maintain positive changes." When a woman has been in and out of jail, she loses everything and feels defeated: "sometimes no matter how hard you try it doesn't work out." Some had lost any sense that the justice system would treat them fairly and were giving up hope.

\section{Now I have a clear mind}

\section{But still confused where will I go when I get out?}

\section{Who will I run to when I am in need of help?}

The women seemed to agree that enough services were available for them, but a major gap existed between knowing what specific types of services were provided and how to access them. One woman spoke about a housing program in a very positive way, while the other women were surprised to hear this program existed. Another woman described the closed doors after getting out, in terms of work, treatment, housing, counseling etc. She said she has nowhere to go and nothing when she got out.

Some of the women spoke about how the system and conditions for release were set up for them to fail, many expected to return to the CRC as a result. Although some woman recognized the need for tight restrictions for parole breaches, others said these restrictions made them want to rebel, rather than to get better for their own sake. Women expressed significant confusion over legal issues. For example, some women stated they did not understand how some of the charges were brought against them because they thought they had already been dealt with.

\section{Lack of a Safe Place}

Lack of access to adequate housing was a significant factor in cycling in and out of remand custody. Some women spoke about how, when on the outside, they would frame their story differently so they could stay in a domestic violence shelter. Single women without children had more difficulty accessing housing than women with children. This could mean, at times, turning yourself in for outstanding warrants or committing a petty crime in order to be remanded back into CRC to be safe.

Being homeless wasn't as hard for me as it was for others, l've always taken advantage of the opportunity when people offered to let me shower or sleep at their place, I was always clean, I never slept outside, l'd rather walk and walk and walk than sleep outside or in a shelter. I was always too scared to do that so l'd walk until I knew someone or got offered by a John for a place to stay. I was always on the run from the police and it was really scary because when homeless there is no place to hide. At times I wanted to turn myself in so l'd have food and a place to sleep but there would be no drugs so I wouldn't, but now that I'm sober I think more clearly and know the right decisions to make, so if I remain this way I'll succeed.

\section{Access to Adequate Income}

The women spoke about the difficulties associated with both having and not having money. Some women 
spoke about the difficulty of having cash upon release, making it tempting to feed their addictions. They said, in some ways, it is better to have others managing their money and giving them vouchers so they would not be tempted - having money easily at their disposal could contribute to negative cycles. At the same time, the women were concerned they would not be able to obtain employment, due to their criminal records: "Who would want to hire a criminal when you could hire someone without a criminal record?"

\section{Fear, Doubt, and Self-Esteem}

Many women appeared to have doubts about how strong they could be when they got out, even with their tremendous drive to do better. One of the women who was soon to be released on bail expressed her fear and doubt, "I want to be on my own, not being used, because then I will be used." Another said she suffered embarrassment on the outside because she had needle marks on her arms and would always have to cover them up. One woman expressed the opinion that when women step out of prison, they are immediately shunned, so they turn back to street life because it is 'safe' and all they know. She said women needed to learn to love themselves. Many of the women seemed to have lost hope that it was possible to break the cycle.

$$
\begin{aligned}
& \text { Maybe l'd like to say l'm sorry } \\
& \text { But to me that's just another story. } \\
& \text { So - l'll continue to sit in my cell, } \\
& \text {-n-wonder where my life fell } \\
& \text {-n-began in hell. }
\end{aligned}
$$

\section{Recommendations for Breaking the Cycle}

Along with the women's stories of how and why they were in the CRC, they shared their thoughts on what needed to be done so they, and others, could break the cycle of repeated incarceration. Primarily, the women identified most of the responsibility for breaking the cycle lies within each individual woman yet recognized the need for the social structure that would support their ability to be successful. We heard stories of hopes and dreams, including "treatment center, upgrading, finish high school, have kids, be sober, go back to normal, get a job, go see kids, go to technical school." The major themes within these recommendations were: connecting with resources including pre-release planning, housing, addiction treatment, and counseling; a strong, positive system of social support and spirituality; and an opportunity to become involved and give back. The women were clear that while they needed these things on an ongoing basis post-release, access to these types of services and opportunities prior to release was critical in helping them to prepare to re-establish themselves in the community.

\section{Connecting with Resources}

The women suggested the best time to connect them with resources was immediately upon release, "just as we are released is the time to grab us, to connect us to resources." They needed help to connect with the resources that would support going to school and creating a different lifestyle for themselves and their children. The women desired more genderspecific programming, noting many more programs exist for men than for women. They wanted integrated services, rather than needing to go to multiple agencies for services, noting it is easier to develop a relationship and respect with one person than with many.

\section{Pre-Release Planning}

The women spoke about the need to interact with services and establish connections to positive support before they were released from remand. They need programming to assist them "to find jobs, a place to live, income for a short while to help us get back on our feet. Some resources for help when we need it, like as soon as we get out. Not having to worry about long waiting lists and lineups."

The women spoke about how difficult it was to get into programs while in CRC. They said for all of the programs, the guards put up a sign-up sheet on the unit, "and then it's first-come, first-served, and most women aren't able to get into anything." The woman recommended more of a system of rotation for the available programs. They also desired a return of the Elizabeth Fry court program-where someone went with them to court to help them understand what was happening and provide support - and a return of the another program that helped them transition out of jail into a normal life.

\section{Safe Housing}

The women all agreed there should be a safe house after remand, somewhere they could go to "organize everything for treatment, money management, housing, parenting classes etc." They wanted a place to go where women could live and learn basic life skills, as a transition out of incarceration into learning how to be 
normal. "I don't want to go get high, I want a place to sleep at night."

\section{Addictions Treatment}

One of the most frequent requests for services both prior to and after release was addictions treatment, although it was challenging to get into treatment. They said the draw of addictions was very strong. Some of the women agreed that, "the key to breaking free of addictions is to cut out the excuses and to hold yourself to a responsibility." One woman said that she wanted to go and get 'clean' for herself, not because she was going to be told by a judge or having to do it for her children. Some also talked about the importance of having a sponsor and surrounding themselves with positive people. "When I am ready I would like to publicly announce 'I' $m$ sober' to the world because that would make me so happy."

\section{Trauma Informed Treatment}

In addition to the need for addictions treatment, some of the women spoke about the need to have counseling, "to relieve me of some problems I feel deep inside." Many carry a burden of guilt for their past behaviors during the times when they were using, knowing how they had hurt their family and friends. One woman said, "I just wish sometimes that I grew up differently or had some kind of will power to say no. I would probably be in a way better place rather than sitting here in what I refer to as 'hell'." Another woman spoke about the need to find 'inner strength.' Some of the women suggested counselors would be more effective if they were 'all-purpose connectors,' rather than having to meet with several different counselors for different issues, making it more difficult to build a relationship with any one person. Counseling should be available both during and after incarceration to help women process their experiences, prepare for, and manage life in the community.

\section{Strong Social Support and Spirituality}

The women spoke frequently about the need to surround themselves with people who would have a positive influence on their lives. Some spoke about knowing they would have to distance themselves from the people they knew through their homelessness and addictions in order to move forward with their lives. They needed friends who could 'call them out on things' and reliable people to lean on. They wanted to be around friends who were not drunk or high. "My dream release plan is to be picked up at the front doors by a sober person."
Many of the women spoke and wrote about the strength gained through their spirituality or religious beliefs. Some spoke about the importance of Native spirituality and "smudging as church." One woman gave her perspective, "religion is for people who don't want to go to hell - spirituality is for those who have been to hell and never want to go back." Another woman questioned in her writing, "I found the Lord, has he found me? Will he help me with all of this confusion? Maybe if I read the Bible or pray more I will not be confused." One woman spoke about her desire to read the Bible from beginning to end while she was in CRC: "I've been reading it since I was a little girl but this is the first time from the beginning."

'Cause God is the one that keeps me going,

He loves me, trusts me, and he's always strong,

For who I am and not for what I have done.

\section{Desire to Give Back}

Occasionally, a woman would talk about how she wanted to make a difference for others, at the same time as helping herself. One said she wanted to volunteer with Aboriginal Elders, so she could hear their stories and gain from their wisdom. Another person said she would like to talk with youth to try to stop "even one life from turning out like ours, because they are the future." Having something positive to do and a project to focus on gives the women a sense of purpose: "I would totally enjoy helping others."

\section{DISCUSSION}

None of researchers had any direct personal experience with incarceration or of dealing with the structural issues faced by the women. Yet, the women shared their stories with us, trusting us to use them in a way that could lead to social change. The women were not ready, both due to their state of remanded custody and to their need to focus on their own survival, to join with us in the creation of social change at this time. They needed to focus on what they could do as an individual rather than try to join us in finding ways to deal with the larger systemic issues. The women who participated in the weekly meetings shared their stories and experiences with us, in order to try to make a difference for themselves and for others. Their words were powerful and left a strong impression on us, changing us, and hopefully giving the women a deeper understanding of their own worlds. In particular, we were struck by the pain in their stories and their ability to look past their histories to hope for a better future. 
Amidst the moments of shared laughter and tears, we all gained a deeper understanding of the issues and some possible solutions.

In many of the women's stories, artwork, and poems, we saw the women's struggle between what they had been and where they wanted to go. One woman depicted this dichotomy in a drawing of herself, split in two between a devil and an angel (Walsh, Rutherford, \& Crough 2013:128). The women were uncertain which side they would be compelled to use upon release. Within the women's stories, they did not appear to acknowledge the impact of the structural system on their experiences but did speak about needing to take responsibility for their futures. As stated by Kruttschnitt and Hussemann (2008:724), "Trying to disentangle agency and structure in the context of the prison experience may be futile." The women were not in a position to think more broadly about the issues they were facing but rather needed to explore their own immediate experiences more fully. As noted by Baskin (2003), the women, and in particular the Aboriginal women, may have internalized their oppressive circumstances, taking on the individual agency view of broader society. "Aboriginal peoples are particularly vulnerable to internalized oppression in Canadian society. There is a constant negative presentation in society, through advertising and the media, lack of representation, and false and degrading images that inferiorize First Nations people" (Baskin 2003:68). Thus, the women continually struggled with the question of whether the devil or the angel would prevail upon release.

The recommendations made by the women are supported in current literature. Salina, Lesondak, Razzoni and Parenti (2011) suggested that traumainformed integrated treatment is an unmet need for most incarcerated women. Similarly, past traumas in the women's lives, and in the lives of those around them, underpinned the paths and choices open to them. Self-destructive behaviors and high-risk activities may serve as a distraction from or medicating the pain from the past. Destructive relationships or compulsive behavioral "reenactments can become addictive and serve as distractions from the internal emptiness and constriction and give the individual the illusion of temporary connectedness, power, control, and relief from loneliness and depression" (Schwartz 2008:575). Some research has connected chaos and addictive behavior to a neurophysiological change in the brain caused by the early exposure to trauma. The chaos has a numbing effect on the associated pain (Van der
Kolk 1988). Thus, treating addictive behavior in someone with a traumatic history is a complex, multidimensional process. This suggests that addictions treatment needs to be accompanied by trauma counseling in order to lead to long-term change.

As the women in this study stated, they are at risk of cycling back into $\mathrm{CRC}$ if released without a safe place to go. "Stable housing is a critical need for prisoners in the period immediately following their release" (Hartfree, Dearden and Pound 2008:3). However, housing options for women who have been incarcerated are limited due to low income, a criminal record, and possible parole or probation restrictions (Severance 2004). Discharge support programs must involve planning where the women will stay immediately upon release, including housing for women who were homeless when arrested, or assistance in regaining housing for those could not maintain their housing during the period of incarceration. Transitional housing, as suggested by the women in this study, would provide a safe housing alternative until longer-term housing arrangements could be made.

Women in this study confirmed the importance of a strong, positive social support system upon release, one of the best predictors of a woman's successful reentry into the community (Bui and Morash 2010, Cobbina 2010, Collica 2010, Fortune et al. 2010). Release planning programs connecting women with mentors and positive social relationships in the community help them to establish a constructive environment in which to return upon release (Fortune et al. 2010, Parsons and Warner-Robbins 2002).

Fundamentally important, within all of the recommendations, is to begin planning for the transition back into the community prior to release. Pre-release planning and transitional services support the women to successfully re-enter society and reduce recidivism (Vigilante et al. 1999, Young and Mattucci 2006). In order to be effective, pre-release planning must be comprehensive and inclusive of all interrelated issues affecting women prior to incarceration and those encountered upon release (O'Brien 2006, Spjeldnes and Goodkind 2009). Planning must also be closely connected with community supports for the reintegration work necessary for the transition from prison to community (Pedlar et al. 2008).

As the women in our study confirmed, intervention to break the cycle of repeated incarceration should begin as soon as possible after entry into the criminal 
justice system (Salina et al. 2011). In particular, attention to basic needs is fundamentally necessary to break the cycle of repeated incarceration. Ideally, interventions need to be in place to reduce the likelihood of women entering the cycle in the first place. Attention to the structural causes and solutions to the cycling in and out of incarceration is fundamentally important and underpins all of the women's recommendations.

\section{Study Limitations}

Each week when the women were brought to the Chapel by the guard, they appeared to be pleased to be there with us. We are aware many may have chosen to participate to have more time out of their cells, or to socialize with the other women, rather than participating in the study itself. At the same time, interactions with those from the outside community may have provided opportunity for respite from the restrictions of the inside (Pedlar et al. 2008). Another limitation was the frequent change in the composition of the women within the group meetings. Both of these factors may have reduced the authenticity and depth of the stories the women shared with us. However, we do not believe this reduced the value of the findings or the richness of the experiences for everyone involved. We did not differentiate the stories of the Aboriginal and non-Aboriginal women in our data analysis, believing enough research has been done on Aboriginal peoples rather than by them (Baskin 2003) and following the principles of ownership, control, access, and possession (OCAP) - that is, research done about Aboriginal people belongs to the Aboriginal people (Schnarch 2004). Thus, analysis of the perspectives of the Aboriginal women was done as respectfully as possible, and may not be as rich as it may have been with more direct Aboriginal involvement in the research processes overall.

Our intent was to make connection with the women while in the CRC, then to establish a way to re-connect in another group setting after release. Unfortunately, we were unable to establish an outside group within the expected time frame. We did, however, remain in contact with several women still in custody through Christmas cards and letters. It was difficult for the researchers to accept this loss of connection and continuity in relationships with the women after spending time together and getting to know them through their stories.

The focus in this article is on the common experiences of the women we spoke within CRC, and their recommendations for systemic change to assist them and other women in breaking the cycle of repeated incarceration. Additional areas of potential analysis emerging in this study could include a deeper examination of arts-based and community-based research methods with marginalized women. In particular, further study could be undertaken related to the usefulness of arts-based research in strengthening individual agency at the same time as influencing change within the larger social structural systems. Further research with expanded ethics approval for an Aboriginal focus could lead to deeper understanding of the distinct issues experienced by Aboriginal women in the justice system (Walsh et al. 2011).

In conclusion, we believe that our study with women at the CRC reveals and confirms the complexity of the cycle of repeated incarceration for women. The women know that they are the ones who need to have the individual agency to take control of what happens in their lives. However, this individual agency must by supported by attention to the need for social structure change in order for the women to succeed. Structural obstacles such as lack of housing, income, education, and employment need to be addressed. The women need extensive and on-going support, both from positive family and friends, but also from integrated and coordinated services that are linked pre- and postrelease. In addition, the women need an opportunity to strengthen their individual agency by being part of the solution and to support one another as they transition back into society. The combination of both individual agency with concerted effort to address the structural issues will positively impact the trajectory of the women's lives. The challenge of reducing the cycle of repeated incarceration for women will require a concerted effort from everyone involved.

\section{REFERENCES}

Allspach, Anke. 2010. "Landscapes of (Neo-) Liberal Control: The Transcarceral Spaces of Federally Sentenced Women in Canada." Gender, Place \& Culture: A Journal of Feminist Geography 17(6):705-23. http://dx.doi.org/10.1080/0966369X.2010.517021

Baldry, E., D. McDonnell, P. Maplestone and M. Peeters. 2006. "ExPrisoners, Homelessness and the State in Australia." The Australian and New Zealand Journal of Criminology 39(1):2033.

http://dx.doi.org/10.1375/acri.39.1.20

Baskin, C. 2003. "Structural Social Work as Seen from an Aboriginal Perspective." Pp. 65-79 in Emerging Perspectives on AntiOppressive Practice, edited by W. Shera. Toronto: Canadian Scholars' Press Inc.

Bui, Hoan and Merry Morash. 2010. "The Impact of Network Relationships, Prison Experiences, and Internal Transformation on Women's Success after Prison Release." Journal of Offender Rehabilitation 49(1):1-22. http://dx.doi.org/10.1080/10509670903435381 
Calverley, Donna. 2010. "Adult Correctional Services in Canada, 2008/2009." Juristat 30(3). (http://www.statcan.gc.ca/pub/85002-x/2010003/article/11353-eng.pdf).

Cobbina, Jennifer. 2010. "Reintegration Success and Failure: Factors Impacting Reintegration among Incarcerated and Formerly Incarcerated Women." Journal of Offender Rehabilitation 49(3):210-32. http://dx.doi.org/10.1080/10509671003666602

Collica, Kimberly. 2010. "Surviving Incarceration: Two Prison-Based Peer Programs Build Communities of Support for Female Offenders." Deviant Behavior 31(4):314-47. http://dx.doi.org/10.1080/01639620903004812

Delman, Jonathan and Alisa Lincoln. 2009. "Service Users as Paid Researchers: Principles for Active Involvement and Good Practice Guidance." Pp. 139-51 in Handbook of Service User Involvement in Mental Health Research, edited by B. Wallcraft, B. Schrank and M. Amering. San Francisco: John Wiley \& Sons.

Fortune, Darla, Julie Thompson, Alison Pedlar and Felice Yuen. 2010. "Social Justice and Women Leaving Prison: Beyond Punishment and Exclusion." Contemporary Justice Review 13(1):19-33. http://dx.doi.org/10.1080/10282580903549128

Foster, Victoria. 2007. "'Ways of Knowing and Showing': Imagination and Representation in Feminist Participatory Social Research." Journal of Social Work Practice 21(3):361-76. http://dx.doi.org/10.1080/02650530701553732

Hartfree, Yvonne, Chris Dearden and Elspeth Pound. 2008. "High Hopes: Supporting Ex-Prisoners in Their Lives after Prison." Vol. Norwich, U.K.: Department for Works and Pensions.

Huss, E. 2009. "A Case Study of Bedouin Women's Art in Social Work: A Model of Social Arts Intervention with 'Traditional' Women Negotiative Western Cultures." Social Work Education 28(6):598-616. http://dx.doi.org/10.1080/02615470903027298

Kruttschnitt, C. and J. Hussemann. 2008. "Micropolitics of Race and Ethnicity in Women's Prisons in Two Political Contexts." British Journal of Sociology 59(4):709-28. http://dx.doi.org/10.1111/j.1468-4446.2008.00216.x

McNaughton, C. and T. Sanders. 2007. "Housing and the Transitional Phases out of 'Disordered' Lives: The Case of Leaving Homelessness and Street Sex Work." Housing Studies 22(6):885-900. http://dx.doi.org/10.1080/02673030701608043

Murray, K. and S. Hick. 2008. "Structural Social Work: Theory and Process." Pp. 1-25 in Structural Social Work in Action: Examples from Practice, edited by S. Hick, H. Peters, T. Corner and T. London. Toronto: Canadian Scholars' Press Inc.

O'Brien, Patricia. 2006. "Maximizing Success for Drug-Affected Women after Release from Prison." Women \& Criminal Justice 17(2):95-113. doi: 10.1300/J012v12n0207.

Parsons, M. and C. Warner-Robbins. 2002. "Formerly Incarcerated Women Create Healthy Lives through Participatory Action Research." Holistic Nursing Practice 16(2):40-49. http://dx.doi.org/10.1097/00004650-200201000-00007

Pedlar, Alison, Susan Arai, Felice Yuen and Darla Fortune. 2008. "Uncertain Futures: Women Leaving Prison and Re-Entering Community." Vol. Waterloo, ON: University of Waterloo. Department of Recreation and Leisure Studies.
Rolling, J.H.J. 2010. "A Paradigm Analysis of Arts-Based Research and Implications for Education." Studies in Arts Education 51(2):102-14.

Salina, Doreen, Linda Lesondak, Lisa Razzano and B. Parenti. 2011. "Addressing Unmet Needs in Incarcerated Women with CoOccurring Disorders." Journal of Social Service Research 37(4):365-78.

http://dx.doi.org/10.1080/01488376.2011.582017

Schnarch, B. 2004. "Ownership, Control, Access, and Possessions (Ocap) or Self-Determination Applied to Research: A Critical Analysis of Contemporary First Nations Research and Some Options for First Nations Communities." Journal of Aboriginal Health 1(1):80-95.

Schwartz, Mark. 2008. "Developmental Psychopathological Perspectives on Sexually Compulsive Behavior." Psychiatric Clinics of North America 31(4):567-86. http://dx.doi.org/10.1016/j.psc.2008.07.002

Severance, Theresa. 2004. "Concerns and Coping Strategies of Women Inmates Concerning Release." Journal of Offender Rehabilitation 38(4):73-97. http://dx.doi.org/10.1300/J076v38n04 05

Shantz, Laura, Jennifer Kilty and Sylvie Frigon. 2009. "Echoes of Imprisonment: Women's Experiences of 'Successful (Re)Integration'." Canadian Journal of Law and Society 24(1):85-106.

Spjeldnes, Solveig and Sara Goodkind. 2009. "Gender Differences and Offender Reentry: A Review of the Literature." Journal of Offender Rehabilitation 48(4):314-35. http://dx.doi.org/10.1080/10509670902850812

Van der Kolk, Bessel. 1988. "The Trauma Spectrum: The Interaction of Biological and Social Events in the Genesis of the Trauma Response." Journal of Traumatic Stress 1(3):273-90. doi: 0894-9867/88/0700-0273\$06.00/0.

Vigilante, Kevin, Mary Flynn, Patricia Affleck, Julia Stunkle, Nathan Merriman, Timothy Flanigan, Jennifer Mitty and Josiah Rich. 1999. "Reduction in Recidivism of Incarcerated Women through Primary Care, Peer Counseling, and Discharge Planning." Journal of Women's Health 8(3):409-15. http://dx.doi.org/10.1089/jwh.1999.8.409

Wallerstein, M. and B. Duran. 2006. "Using Community-Based Participatory Research to Address Health Disparities." Health Promotion Practice 7(3):312-23. http://dx.doi.org/10.1177/1524839906289376

Walsh, C.,G. Rutherford, and M. Crough. 2013. "Arts-Based Research: Creating Social Change for Incarcerated". Women, Creative Approaches to Research6(1):119-139.

Walsh, C., G. Rutherford and N. Kuzmak. 2009. "Characteristics of Home: Perspectives of Women Who Are Homeless." The Qualitative Report 14(2):299-317.

Walsh, C. A., P. MacDonald, G. E. Rutherford, K. Moore and B. Krieg. 2011. "Homelessness and Incarceration among Aboriginal Women: An Integrative Literature Review." Pimatisiwin: A Journal of Aboriginal and Indigenous Community Health 9(2):363-85.

Young, Diane and Robert Mattucci. 2006. "Enhancing the Vocational Skills of Incarcerated Women through a Plumbing Maintenance Program." The Journal of Correctional Education 57(2):126-40.

(c) 2014 Rutherford et al.; Licensee Lifescience Global.

This is an open access article licensed under the terms of the Creative Commons Attribution Non-Commercial License (http://creativecommons.org/licenses/by-nc/3.0/) which permits unrestricted, non-commercial use, distribution and reproduction in any medium, provided the work is properly cited. 